\title{
NARRATIVES OF WOMEN ON HEMODIALYSIS: WAITING FOR A KIDNEY TRANSPLANT
}

\author{
Soraia Geraldo Rozza Lopes ${ }^{1}$, Denise Maria Guerreiro Vieira da Silva²
}

\footnotetext{
${ }^{1}$ Doctoral student at the Graduate Program in Nursing (PEN) at the Universidade Federal de Santa Catarina (UFSC). Florianópolis, Santa Catarina, Brazil. E-mail: so_rozza@hotmail.com

2 Ph.D. in Nursing. Associate Professor at the Nursing Department and at PEN/UFSC. Florianópolis, Santa Catarina, Brazil. E-mail: denise@ccs.ufsc.br
}

\begin{abstract}
The objective of this study was to understand the meanings of waiting for a kidney transplant for women on hemodialysis. This is a qualitative, interpretive study, conducted with 12 women on hemodialysis in the metropolitan region of Florianópolis. Data were collected through in-depth interviews at the homes of the participants. Ethnograph 6.0 software was used for pre-coding and interpretative analysis was done subsequently, from which two categories emerged. The first, "the shadows of the present moment," showed that the initial difficulties of the disease are present, but women can cope better with the disease and treatment. The second category, "the light of renal transplantation", shows the hope fostered by entry on the waiting list for a transplant.
\end{abstract}

DESCRIPTORS: Women. Renal insufficiency, chronic. Kidney transplantation. Dialysis.

\section{NARRATIVAS DE MULHERES EM HEMODIÁLISE: À ESPERA DO TRANSPLANTE RENAL}

RESUMO: O objetivo do estudo foi compreender os significados da espera do transplante renal para mulheres em tratamento hemodialítico. Trata-se de um estudo com abordagem qualitativa, interpretativa, realizado com 12 mulheres em tratamento hemodialítico na região da Grande Florianópolis. A coleta de dados ocorreu por meio de entrevista em profundidade, no domicílio. Foi utilizado o software Etnografh 6.0 para a pré-codificação e feita a posterior análise interpretativa, de onde emergiram duas categorias. A primeira, "as sombras do momento atual", mostrou que as dificuldades iniciais da doença estão presentes, mas as mulheres conseguem lidar melhor com a doença e o tratamento. A segunda categoria, "à luz do transplante renal", evidencia a esperança promovida pela entrada na fila de espera pelo transplante.

DESCRITORES: Mulheres. Insuficiência renal crônica. Transplante de rim. Diálise.

\section{NARRACIONES DE MUJERES EN HEMODIÁLISIS: LA ESPERA PARA UN TRASPLANTE DE RIÑÓN}

RESUMEN: El objetivo del estudio fue comprender el significado de espera del trasplante renal para las mujeres en hemodiálisis. Se trata de un estudio cualitativo-interpretativo, realizado con 12 mujeres en hemodiálisis en Florianópolis. Los datos fueron recolectados a través de entrevistas en profundidad en el domicilio. Fue utilizado el software Etnografh 6.0 para la pre-codificación y posterior al análisis interpretativo emergieron dos categorías: "las sombras del momento actual", que mostró que las dificultades iniciales de la enfermedad están presentes, pero las mujeres pueden hacer frente mejor a la enfermedad y el tratamiento. La segunda categoría, "la luz del trasplante renal", muestra la esperanza impulsada por la entrada en la lista de espera para un trasplante.

DESCRIPTORES: Mujeres. Insuficiencia renal crónica. Trasplante de riñón. Diálisis. 


\section{INTRODUCTION}

Chronic renal failure is the progressive and usually irreversible loss of kidney function. It is a disease on the rise in Brazil and worldwide, and currently one of the major public health problems. ${ }^{1}$ Treatment consists of three modalities: hemodialysis, peritoneal dialysis and renal transplantation. Hemodialysis is a treatment in which the patient's circulation is performed in an extracorporeal manner, and the blood, with the aid of a pump, passes into a dialyzer (artificial membrane) which, in contact with dialysis solution prepared in the machine, promotes blood filtration. Peritoneal dialysis is carried out by the introduction of saline solution with dextrose in the peritoneal cavity, by means of a catheter implanted in the intraabdominal region. This solution, in contact with the peritoneum, performs the removal of toxic substances from the blood. Renal transplantation is a surgical procedure in which the person receives a kidney from a living or cadaveric donor. ${ }^{2}$

In Brazil, the most common treatment is hemodialysis, performed predominantly in males. Over the past 10 years, however, there has been a significant increase in the number of women with chronic renal failure who undergo hemodialysis. ${ }^{3}$ The 2011 Census showed that, of the 50,128 people on hemodialysis, 21,389 were women, representing a significant and compelling number of new studies. ${ }^{3}$

People on hemodialysis are accompanied by multidisciplinary teams and given orientation about the possibility of kidney transplants; they then begin examinations and consultations to ascertain compatibility and proceed to entrance on the waiting list for renal transplantation. Faced with this possibility, special care is required to help patients keep themselves active and in favorable condition for transplantation. This generates expectations among people on the waiting list, who are aiming to not require hemodialysis anymore and have a better quality of life, with more freedom. ${ }^{4-5}$

We have observed that, over the years, the topic of transplantation and organ donation has been in evidence in Brazil and in the world, due to the growth in the number of transplants. ${ }^{6} \mathrm{Nev}$ ertheless, renal transplantation requires waiting time, as evidenced in a study indicating that in $2008,19,125$ transplants of various organs and tissues were carried out in Brazil, of which 3,154 were kidney transplants. ${ }^{7}$ In 2012, in Santa Catarina, 122 kidney transplants (cadaveric or living) were performed, and in August 2012, 398 people were registered on the waiting list. ${ }^{8}$

In this work, we opted to focus on women who have chronic renal failure. This choice is anchored in aspects related to gender issues and differences between the genders. First, taking into account the different roles of men and women in society, especially in families, which are considered the main psychological and organizational support for all members. With the discovery of chronic disease, and implementation of treatment, many changes occur, which can disrupt patients' lives and family environment. ${ }^{9}$

Another aspect worth mentioning is the biological (or physiological) differences between men and women. The existence of inequalities in access to renal replacement therapy has been shown by some research. ${ }^{10-11}$ This inequality in access, and also in receiving transplants, is shown by lower probability that women will be assigned to the waiting list. The probable reason is that women have a high level of panel-reactive antibodies induced by pregnancy, which would contraindicate transplants. ${ }^{10}$

Little is known about what women think about kidney transplantation and what it means in their lives, due to the scarcity of studies on this topic. Another aspect that justifies the study conducted is that transplantation is not the focus of attention by nursing professionals working in hemodialysis services, which only focus on activities related to hemodialysis, leaving these women with many doubts about everything regarding transplantation.

We believe that this study may increase the understanding of nursing staff about the context of renal transplantation, especially for women on hemodialysis, thus improving support for these people. This care could be directed more toward fostering understanding of the condition of being a woman with chronic renal failure. This could work to increasingly orient women toward transplantation and aftercare, which could influence their decision to get a transplant. Therefore, our objective was to understand the meanings of the wait for renal transplantation for women on hemodialysis. In the context of the narrative, there are also few studies, and if we think about studies aimed at women, we have found no studies with these characteristics. The search for narratives originated from the interest in finding out about the details of women's experiences, what happens during their conservative treatment routine and in 
the carrying out of examinations considering the wait for a transplant.

\section{METHOD}

This is a study with a qualitative, interpretive approach, having the ethnographic approach as a reference.

The research was conducted at a satellite clinic located in Florianópolis, Santa Catarina. The site for the study was selected based on ease of entry into the field, and also due to the support and interest of the institution and the professionals who are part of it. At the time of the study, this institution attended approximately 110 people on hemodialysis, with most of them being attended by the United Health System. Of these, 42 were women. This service includes a team of nephrologists, a social worker, a nutritionist, nursing technicians and nurses.

Participants were chosen based on the following inclusion criteria: a minimum age of 18 years; on hemodialysis for more than one year; on the waiting list for a transplant or conducting examinations for entry on the waiting list for transplantation. The exclusion criteria were: change in behavior; communication difficulties or hearing problems; no clinical conditions for transplantation. In collaboration with the nurse in charge, a list of women who met the inclusion criteria was compiled, indicating the days and times of hemodialysis, to perform first contact. This list contained 20 women, of whom 12 were selected to join the study. This number was defined by consistency of interviews and data obtained, which made achieving the proposed objective possible. First contact took place in the institution, when we extended the invitation to participate in the study and explained the objectives, and the women read and signed the Free and Informed Consent Form.

Data collection occurred through in-depth interviews, carried out from January to March 2012. The objective of the interviews was to get to know the stories of women about hemodialysis and waiting for kidney transplants. In these interviews, we used leading questions to encourage them to tell the story of their chronic illness, such as: Tell me how your kidney problem started. How was your life at that time? How was it when you started hemodialysis? How did you hear about the kidney transplant? From the answers to these questions, others emerged, in order to meet the study objective, until reaching data saturation. The interviews were recorded and transcribed by the interviewer with the assistance of a trained helper.

Ethnograph 6.0 software was used for data organization and carrying out pre-coding of all interviews, aiming to identify content. This resulted in 216 codes, which were grouped by affinity. For example: "adaptation of life" was grouped with post-hemodialysis activities, impact of the discovery, impact of early treatment, instability in treatment, hemodialysis limitations, daily activities, change in routine, life-changing situation, and surprise of the diagnosis. Thereafter, we carried out interpretative analysis, so as to give meaning to the codes. In this process, it was necessary to return several times to the interviews, enabling us to grasp the expression from the narrative of these women; which then fell into two categories: "the shadows of the present moment," and "the light of renal transplantation".

This research met the guidelines for research with human beings, guided by Resolution No. 196/96 of the National Health Council. The study was approved by the Research Ethics Committee on Human Beings at the Universidade Federal de Santa Catarina, with process number 2411 and FR: 482837. To guarantee the anonymity of the participants, they are identified as M1, M2, M3, and so on.

\section{RESULTS AND DISCUSSION}

The two categories identified express the narratives of women with chronic kidney disease who are on hemodialysis. The first category was called "The shadows of the present moment" and shows the reality of their lives, in which the darkness of the disease appears at times; but they can also realize their possibilities, especially arising from the light that the chance of a transplant brings, which also has its shadows, such as the difficulty and insecurity of the wait. The second category was "In the light of the renal transplantation," which showed the time in the disease when they entered the waiting list for transplantation, and this becomes a source of hope, a light in their lives.

\section{The shadows of the present moment}

The shadows express the current condition, between the darkness of the discovery of the disease, when all light seems to be lost, and the clarity that may arise with a transplant. At this stage, the women attempt to accept the chronic condition and the treatment, seeking to emphasize the positives that hemodialysis promotes. All this, 
however, is punctuated by moments of sadness, fear, hope, anger and frustration.

In these shadows, there is also lack of information about transplantation, coupled with maintenance of good health conditions that can make it possible and regular testing. Moreover, the women experienced the loss of the possibility of a transplant and sometimes observed the loss of a transplanted kidney in other people who have already had the surgery and returned to hemodialysis. In the so-called "present moment," the women proved to be in a phase of acceptance of the disease and, especially, the treatment. Although the treatment led to a period of restrictions and limitations in their lives, even so, in their narratives, they mentioned the need to perform hemodialysis and accepted the fact that, today, what enabled them to have a life was a machine that filtered their blood.

Hemodialysis sessions can be described as a seesaw, with positive and negative sides. It turns out that, being a seesaw, there are days when it weighs more on one side, and there are days that it weighs more on the other.

The first time I went to do hemodialysis in Tubarão, there were some stairs with six steps, the first thing I said to my husband was, 'You'll have to carry me up, because I won't be able to climb these stairs'. So he helped me up the stairs, and the other day when I went to do hemodialysis, I was already climbing the stairs alone. So, my entry on hemodialysis was like this, there are things that get better and things that don't, they get worse. But I can tell you that doing the treatment is really worth it. The good side is that you get well [...] (M1).

Over time, the hemodialysis sessions have been incorporated into the women's routine and they come to spend time other people in treatment, three days a week, creating ties of affection and, sometimes, even considering how to construct a new family. This interaction with their peers during the hemodialysis session helped minimize the feeling that they were not normal, because they were there among individuals who experienced the same reality.

Another element was faith in God, which appeared in many narratives as a source of support. When they had faith, they could look around and realize that there were situations even worse than theirs, and this meant that they had the strength to face their current condition in life.

[...] so God gives me so much, I have a lot offaith. I recently said to Carla, it's not that I'm evangelical, those kind of things, but I always say, 'God loves me a lot because, for me, to be here today talking, there have been ups and downs,' so, I'm still up for it [...]. I once read a quote that, as hard as your life may be, look around you, there's always someone worse. And look how it is, after I'm there, some patients have died. There is a lady who goes there, she goes in the morning, who is really skinny, my God! I look at her and say, 'This woman is a fighter' [...] (M2).

The expectation of transplantation was always present, sometimes as a cause of joy and hope, or as a cause of anxiety and frustration. ${ }^{12}$ The women expressed happiness knowing that their hemodialysis colleagues were getting transplants, that the post-transplant was positive; but, at the same time, they demonstrated their revolt because they were not being chosen for transplantation. The expectation of being chosen for transplantation generated constant anxiety, because they were on 24-hour alert for a possible call. They often deprived themselves of leaving home for fear of not being located.

Reference to special care to remain in a healthy condition for the transplant was also frequent, especially avoiding contact with people with colds, coughs, pneumonia or other diseases. This situation of waiting caused anguish, because they realized that the loss of a chance for a transplant would be devastating. Therefore, the uncertainty of being called for the transplant was always present, with the feeling that they were floating in possibilities; but, in reality, there was nothing concrete, i.e., they did not know if, one day, they would ever have the opportunity for it to happen.

It was just like that: they called my daughter, but where my daughter lives, it is horrible to get to the phone. It's horrible, horrible to get to the phone! So, my daughter got there and saw the call. Then, when she went to the phone, there was a strange call, several strange calls on her phone. She decided to call to see whose number it was, who it was, so she spoke with Adriana, spoke directly with Adriana, already very early in the morning. She saw the phone and she then came straight to my house, she came here, I still had not seen my phone, I still had not even touched my phone. She arrived here and said, 'Mother in heaven, something has happened to you!'. I thought it was something bad. 'You have been called, mother, for the transplant, and you still have not seen it, where is your phone?' Because the phone has to be in the room with us. Now I've learned, I put one there, one there and one in my room, I have a phone in my room. Then she went and said, "My God," she was crying so hard, this young kid, 
she was crying so much... she stayed like that... Then we hugged, then we cried a lot, both of us, and she told me to accept it myself, but at the same time, she could not accept it. So that's how I found out, from then on I looked at my cellphone and I also saw the same call. So, then I went there the other day, I went to the clinic, the $X$ clinic, and I spoke with Dr. R. and he said: 'Bah, Girl, what happened to you, why didn't you come?' I said: 'Look, basically, I was just at home, but I did not hear the phone ring.' How many days did I not go upstairs, to the country home, scared, because there is no phone there, and I could not see at home [...] (M9).

Information about the transplant is not accurate, especially about the process of transplantation or what life will be like as a person who has had a transplant. So, concern is more focused on the monthly tests, with the concern that everyone is within what is normal or close to it. These precautions involve properly feeding oneself, and also performing the dialysis sessions satisfactorily and, especially, fluid restriction, identified as the greatest difficulty.

And blood tests are good, all other tests were good. Only phosphorus and potassium were a little high, but Dr. T. said it's not too serious, but I just have to take care. This month I am taking care of myself a lot, and so, as regards diet and what I eat most, it's bread, not to eat too much salt, not eating too much salty food. Bread, cream cheese, that white cheese, or if not, that light cream cheese, light yogurt, just a little. I like pasta, rice, chicken, steak, that's just the way it is, we have to eat something. And, then, lime oranges, what I like most is lime oranges, Argentine pears. And I was eating a lot of prunes, but they say that plums have a lot of potassium, I thought they didn't, but they have a lot of potassium. So that's how it is, us two, me and my dad, we vary. Sometimes a coconut bar, because my father is very fussy when it comes to eating [...]. Sometimes polenta, you know, sometimes we eat polenta with chicken, and that's how we keep on going. But I eat a lot of bread, there is no wrong time to eat bread, then cupcakes, just like that (M9).

The narratives revealed that in the moment there was light and darkness, which generated the shadows of living with constant possibilities and uncertainties. They could accept their chronic condition and hemodialysis, but it was never complete acceptance. There were always moments of outrage, conflict and uncertainty. But hope always appeared to put a little more light in their lives.

The initial suffering indicated the disruption in the routine of life and the appearance of uncertainties about the women's bodies and future.
They came to live in a distinctive world, which was the environment of the hemodialysis service, with connection to the machines, frequent contact with healthcare professionals and with unknown people in similar circumstances. This moment can be called liminality, considered as the experience of the disruption of life due to a serious or chronic illness, in this case, chronic kidney failure. ${ }^{13}$ This experience can cause anxiety, stress, uncertainty and the fear of death, and all this leads to uncertainty about the future. ${ }^{4}$

These reports also showed a gap in the care provided by nursing staff, which is not focused on the real needs of women with chronic renal failure on hemodialysis, who expect the possibility of renal transplantation. We realized that in the hemodialysis environment the focus is on preparing the machines, replacement of materials, and organization of the rooms. People stay for four hours in direct contact with nursing services and they leave with doubts, questions and difficulties in coping with chronic kidney disease and its treatment. Experiences of these people in society and the family is often fragile; so nurses and staff should focus on these experiences in order to discuss and find solutions for these issues. ${ }^{14}$

\section{In the light of the renal transplantation}

This category focuses on the kidney transplant as a life perspective, considering that it is a remote possibility, just like the lottery. It is the best treatment option in the quest for normality, for a better quality of life and the redemption of the freedom to live.

This hope permeated the narratives of the women interviewed when referring to the possibility of transplantation. The symbology of the transplant is that of renaissance in the midst of chronic illness, it is what brings the prospect of a long life. When considering renal transplantation as the best treatment option, some women mentioned that they would like to have had it as the first treatment option, instead of hemodialysis. However, transplantation requires entering a waiting list, and the possibility is considered remote.

Ah, wondering if I had had a kidney transplant, it would change everything! Because, if I feel well, if only because of a transplant, because they don't all work out, it's a lottery. A transplant is a lottery, but do I want this game, I want to play. Because the only problem I have is my kidney. If I put in a kidney, do a transplant, I'll feel fine, I'll be happy, I'll feel good, I'll 
be a normal person. I'll go back to work, I'll go back to drinking, not drinking too much, and I can't abuse anything, anything at all! But just the fact that I will be that perfect person again and with a long life expectancy, that's it [...] (M9).

A study that sought to understand the perceptions of people on the waiting list for renal transplantation showed hope in many of the interviewees' comments and highlighted the perception of the kidney transplantation as a driver in changing one's life, associated with greater will to live and certainty of living, no more need for hemodialysis. ${ }^{15}$ Hope is always a factor evidenced in studies relating to people with chronic diseases. This feeling appears as a source of support and strength in seeking treatment and in the maintenance of life. ${ }^{16}$ Hope, therefore, is associated with the fact that kidney transplantation could change their lives, and provide them with a return to previous activities. ${ }^{15,17}$

During renal treatment, and waiting for a transplant, the women interviewed had contact with people who had already undergone renal transplantation, and this further increased the expectation that the transplant would bring back their previous life. They referred to this possibility of transplantation as a new life.

I know people who had a transplant and they went well. I know a lot of people who have had them. Besides my aunt, there is a young man who has already had one, and sometimes I talk to him. There are some here too, but out of here, it is only him. And he says it's nothing scary, it's not something for me to get scared about, that people are afraid, they think it will hurt. But it's not scary at all, it wasn't for him, and his recovery was very fast and he's had both done already. Thinking about both of them, he recovered quickly and then went back to a normal life, and I can even tell you that he is already working again. And I heard about cases here in the clinic that did not work out, only about people from here, but I know that there is this risk. Even having the risk, I have to try, at least I have to try. If someone shows up who fits into these remaining $9 \%$ and I don't try, I'll never know, at least I have to try and risk it [...] (M7).

The search for normality finds, in kidney transplantation, the output that would enable them to get back to the physical condition allowing the women to carry out everyday activities. They referred to a previous life of health and freedom, longing for the transplant to enable them to return to work, study, wander freely and perform domestic chores. They associated this with normality.

Renal transplantation has been perceived by the people who need it as the only alternative allowing them to leave the suffering that permeates their lives, to promote rebalancing after the disorder caused by hemodialysis. ${ }^{18-19}$

Another question widely implicated in studies of people with kidney failure is freedom. People with the disease allude to the absence of freedom, linked to the fact that they live according to the hemodialysis treatment schedule, requiring going to the hospital three times a week for four-hour sessions on average. ${ }^{15}$

Just the fact of not having to go out using the machine is a release, because you're in a prison. You cannot go on without doing anything, I never ventured out without having nothing to do, I'm terrified of being here with nothing to do. Getting there and having nothing to do, all right, but I've never been without this, because I'm afraid of running out of something to do. I had a fistula on Friday and the doctor said, 'You don't need to go tomorrow,' which was a Saturday. I got scared and went there late, at 5 a.m. I woke my husband and I went there, I was afraid [...] (M11).

Comparing hemodialysis and renal transplantation, a differential factor in the reports is the idea of transplantation as freedom. Making an analogy to a bird, it's as if the woman understands hemodialysis as her cage, and transplantation as the immense sky for her flight.

People with chronic renal failure undergoing hemodialysis experience particular conditions, such as the need to access health services, dependence on hemodialysis services, physical losses, the need to control diet, and the need to reduce their workload, which affects the household budget. All of this means losses to both the sick people and their families. ${ }^{19}$ Facing this period as a big challenge, transplantation becomes the chance to regain the freedom that was taken from them. ${ }^{20}$

Transplantation is also viewed as the resumption of happiness, since, as stated earlier, the women feel constrained to a limited and sad life. The transplant could give them a life where they could be happy again, recover their physical strength, be able to eat a diet that makes them stronger, and be able to rebuild their self-image, weakened by the disease and the treatment.

Only after the transplant I believed that I'd become stronger, to be able to strengthen my body more. I am also very thin, so, I will sweep the house, sweep a little, and get tired, then I'll do the dishes, wash a little, and get tired. So, I have to do a little bit, stop a bit, do a bit, stop a bit. So it's good to get invigorated again, doing things alone, so this way I'm always screaming: 
'Mother in law! Auntie Regina!' I'm always yelling at them, for them to come and help me [...]. Having a transplant is being able to be happy, it is to have more time to live, you know, to get well, not to be fallen, just like me [...] (M1).

Similar results were found in a study ${ }^{21}$ that sought to understand the assignment of the meanings of kidney transplant, and provide input and data about feelings (fear, anxiety, sadness) expressed by people who are waiting for a transplant.

The transplant can be viewed as a way to improve the quality of life. The survival benefit of kidney transplantation is clear; compared with dialysis, people selected for this surgery show increased life expectancy of about 17 years, compared to dialysis patients with only six years of survival after starting treatment. ${ }^{22}$ Despite a higher initial risk of death, survival in the long term for individuals undergoing transplantation is significantly better compared to those who are on the list, but remain in dialysis. A successful transplant triples the life expectancy of a person with renal failure on the waiting list. ${ }^{21}$

Another important aspect in relation to chronic kidney disease is that, according to one study, women are less likely to be placed on the waiting list for a transplant. The probable reason for this is that women have a high level of panelreactive antibodies induced by pregnancy, which may contraindicate transplantation. ${ }^{23}$ The women waiting for transplantation do not know that they have lower odds of transplantation; there are few studies that reveal the reality of transplantation in women; and the assistance given in dialysis services is not related to gender.

\section{FINAL CONSIDERATIONS}

These narratives revealed that the performance of hemodialysis is vital, the wait for a transplant is inevitable and the success of the procedure is not predictable. The only certainty is that courage and strength are required to continue to live in the best way possible, undergoing dialysis while waiting for a transplant.

The results allow us to reflect on how this disease promotes suffering and requires a great effort from the women in the search for survival. We understand that this condition causes problems in different aspects of the life of these women, especially psychologically. We understand, too, that the way they perceive these experiences and the support they receive influence the acceptance of their condition. The meaning that the women give to renal transplantation is the possibility of a more definitive treatment, which can change their lives and transform an extremely difficult reality into better days. The possibility of a transplant helps them to face the day-to-day drudgery of treatment and emerges as a dream of starting over.

This points to the need to redesign our care so that it is focused not only on immediate care, but also on anticipating the needs of these women, such as, for example, the expectation of transplantation. We can also highlight that, even in turbulent times, we need to guide people to be able to cope with the disease, prompting them to have expectations and new perspectives on the darkness or shadows of their lives with chronic kidney disease and on hemodialysis, in the hope of advancing comprehensiveness of health care for this population.

\section{REFERENCES}

1. Lugon JR. Doença Renal Crônica no Brasil: um problema de saúde pública. J Bras Nefrol. 2009 JanMar; 31(Supl.1):2-5.

2. Riella MC. Princípios de nefrologia e distúrbios hidroeletrolíticos. $5^{\mathrm{a}}$ ed. Rio de Janeiro (RJ): Guanabara Koogan; 2010.

3. SBN - Sociedade Brasileira de Nefrologia [página na internet]. São Paulo (SP): Sociedade Brasileira de Nefrologia; 2011 [acesso 2012 Jun 12]. Censo de diálise. Disponível em: http:/ / www.sbn.org.br/ pdf/censo_2011_publico.pdf

4. Silva ASD, Silveira RSD, Fernandes GFM, Lunardi VL, Backes VMS. Percepções e mudanças na qualidade de vida de pacientes submetidos à hemodiálise. Rev Bras Enferm. 2011 Oct [acesso 2014 Fev 11]; 64(5):839-44. Disponível em: http:/ / www. scielo.br/scielo.php?script=sci_arttext\&pid=S003471672011000500006\&lng=en

5. Burns T. Waiting for a kidney transplant in Australia - latest trends [online]. Transplant J Australas. 2013 Jul [acesso 2014 Feb 12]; 22(2):10-5. Disponível:http:/ / search.informit.com.au/docu mentSummary;dn=494465714293729;res=IELHEA

6. Pruinelli L, Kruse MHL. Biopolítica e doação de órgãos: estratégias e táticas da mídia no Brasil. Texto Contexto Enferm [online]. 2011 Dez [acesso 2014 Fev 11]; 20(4):675-81. Disponível em: http:/ / www. scielo.br/scielo.php?script=sci_arttext\&pid=S010407072011000400005\&lng=en

7. Marinho A, Cardoso SS, Almeida VV. Disparidades nas filas para transplantes de órgãos nos estados brasileiros. Cad Saúde Pública [online]. 2010 [acesso 2012 Jun 12]; 26(4):786-96. Disponível em: http:/ / dx.doi.org/10.1590/S0102-311X2010000400020 
8. SC Transplante [página na internet]. Florianópolis (SC): Secretaria de Estado da Saúde; 2012 [acesso 2012 Jul 12]. Dados doação e transplante. Disponível em: http://sctransplantes.saude.sc.gov.br/ images/2012/junho\%202012.pdf

9. Miranda DS, Lobato SEM. Processos de adoecimento ligados ao gênero: uma história de (des)valorização dos múltiplos papéis femininos. Ciênc Saúde [online]. 2007 [acesso 2012 Jun 20]. Disponível em: http:/ /artigocientifico.com.br/uploads / artc_1206559548_43.pdf

10. Machado EL, Caiaffa WT, César CC, Gomes IC, Andrade EIG, Acúrcio FDA, et al. Iniquities in the access to renal transplant for patients with end-stage chronic renal disease in Brazil. Cad Saúde Pública [online]. 2011 [acesso 2014 Feb 11]; 27(Suppl 2):28497. Disponível em: http://www.scielo.br/scielo. php?script $=$ sci_arttext\&pid $=$ S0102311X201100140 0015\&lng=en

11. Feehally J. Ethnicity and renal replacement therapy. Blood Purif. 2010 Jan; 29(2):125-9.

12. Moran A, Scott A, Darbyshire P. Waiting for a kidney transplant: patients' experiences of haemodialysis therapy. J Adv Nurs [online]. 2011 [acesso $2014 \mathrm{Fev}$ 10]. 67(3):501-09. Disponível em: http:/ / www.ncbi. nlm.nih.gov/pubmed/20955183

13. Molzahn AE, Bruce A, Sheilds L. Learning from of people story wich chronic kidney disease. Nephrol Nurs J. 2009 Jan-Fev; 35(1):13-20.

14. Nogueira PCK, Feltran LdS, Camargo MF, Leão ER, Benninghoven JRCS, Gonçalves NZ, et al. Prevalência estimada da doença renal crônica terminal em crianças no estado de São Paulo. Rev Assoc Med Bras [online]. 2011 Aug [acesso 2014 Feb 11]; 57(4):443-49. Disponível em: http:/ / www. scielo.br/scielo.php?script=sci_arttext\&pid=S010442302011000400020\&lng=en. http://dx.doi. org/10.1590/S0104-42302011000400020

15. Flores RV, Thomé EGR. Percepções do paciente em lista de espera para o transplante renal. Rev Bras Enferm [online]. 2004 Nov-Dez [acesso 2012 Jul 01]; 57(6):687-90. Disponível em: http:/ / www.scielo.br/ pdf/reben/v57n6/a11.pdf

16. Balsanelli ACS, Grossi SAA, Herth K. Avaliação da esperança em pacientes com doença crônica e em familiares ou cuidadores. Acta Paul Enferm [online]. 2011 [acesso 2012 Jun 10]; 24(3):354-8. Disponível em: http://dx.doi.org/10.1590/S010321002011000300008

17. Pietrovski V, Dall'Agnol CM. Situações significantes no espaço-contexto da hemodiálise: o que dizem os usuários de um serviço? Rev Bras Enferm [online]. 2006 Set-Out [2012 Jun 22]; 59(5):630-5. Disponível em: http://www.scielo.br/pdf/reben/v59n5/ v59n5a07.pdf

18. Roso CC, Beuter M, Kruse MHL, GirardonPerlini NMO, Jacobi CDS, Cordeiro FR. Self-care of patients in conservative treatment of chronic renal insufficiency. Texto Context Enferm. 2013 Sep [acesso 2014 Feb 11]; 22(3):739-45: Disponível em:http:/ / www.scielo.br/scielo.php?script=sci_ arttext\&pid=S0104-07072013000300021\&lng=en

19. Magi S, Frankland J, Long-Sutehall T, AddingtonHall J, Mason J. Seeking Normality: Life on the Kidney Transplant List [online]. 2012 [acesso 2012 Jun 03]. Disponível em: http://www.wlv. ac.uk/pdf/Kidney\%20transplant\%20list\%20sque_ book\%20weimar.pdf

20. Mattos M, Maruyama SAT. A experiência em família de uma pessoa com diabetes mellitus e em tratamento por hemodiálise. Rev Eletron Enferm [online]. 2009 [acesso 2012 Jun 12]; 11(4):971-81. Disponível em: http://www.fen.ufg.br/revista/ v11/n4/v11n4a23.htm

21. Quintana AM, Santos TK, Hermann CW. Atribuições de significados ao transplante renal. Psico [online]. 2011 Jan-Mar [acesso 2012 Jan 15]; 42(1):23-30. Disponível em: http://revistaseletronicas.pucrs. br/ojs/index.php/revistapsico/article/view/ 6057

22. Oniscu CG, Brown H, Forsythe JLR. Impact of cadaveric renal transplantation on survival in patients listed for transplantation. J Am Soc Nephrol [online]. 2005 Jun [acesso 2012 Jan 20]; 16(9):185965. Disponível em: http://jasn.asnjournals.org/ content/16/6/1859.short

23. Machado EL, Cherchiglia ML, Acurcio FA. Perfil e desfecho clínico de pacientes em lista de espera por transplante renal, Belo Horizonte (MG, Brasil), 2000-2005. Ciênc Saúde Coletiva. 2010; 16(3):1981-92. 